\title{
The new federal health strategy: give the money and run
}

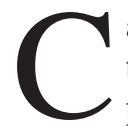

anada's government marked the end of 2011 by shattering the hopes of health professionals and their patients. Less than a week before Christmas, federal Minister of Finance Jim Flaherty revealed the government's intention to proceed with its own plan for future funding of the federal health transfer. ${ }^{1}$ The plan is devoid of both provincial obligations and provincial input. This pre-emptive federal strike, if enacted as planned, will scuttle the much anticipated renegotiation of Canada's federal-provincial health accord. Those of us who expected this process to create an opportunity at long last to address systemic health care problems that we and our patients grapple with daily can instead only bear witness to another squandered opportunity for health care reform.

In what seems to be a hallmark of the Harper government's approach to federal-provincial relations on health, ${ }^{2}$ Flaherty revealed the new plan in a surprise announcement to his provincial counterparts behind closed doors. While the plan extends a funding arrangement for the federal health transfer until 2024, the annual increase in funding will remain at the present 6\% level only until 2016-17 and will be lower thereafter, based instead on the growth rate in nominal gross domestic product (GDP).

This funding will not be tied to incentives - not even the few associated with the 2004 accord. Thus, the plan contains nothing to address the lack of provincial accountability for health spending, which historically has frustrated efforts at both cost control and establishment of national standards. Without countervailing federal action, a real danger exists that the principles of the Canada Health Act, notably universality and comprehensiveness of health care, will become no more than a distant dream.

The federal government asserts that its new plan is fiscally responsible and establishes clarity and certainty for provincial health care funding. But tying future increases in the federal transfer to the varying and unpredictable performance of the economy would seem instead to embed uncertainty into the process. Also, because federal and provincial GDPs tend to be closely linked, it would make additional federal support for health care lowest at times when provincial budgets will likely also be the most strained.

Tinkering with the amount of money transferred while continuing to shovel money to the provinces without demanding anything in return is not fiscally responsible. True fiscal responsibility would instead be shown by tackling the systemic gaps and inefficiencies that are driving increased health care costs. We and our patients experience examples of these continually: preventable illnesses in those who cannot afford effective medications; delay and duplication in treatment due to a lack of point-of-care access to comprehensive medical records; repeated and prolonged hospital stays in the context of inadequate access to affordable long-term or community care; a physician remuneration system with a legacy of perverse incentives incongruent with the realities of patient care. The 2004 health accord led to promised action on measures to address some of these problems, including national pharmacare and primary care reform, but it has yet to deliver. Other important measures such as e-health urgently await attention.

Flaherty stated, "We want to put the issue of funding behind us to allow us all to focus on the real issue - how to improve the system."' Such words ring hollow coming from a government that has given little or no indication for years that it considers improving the health care system a priority. As a consequence, the Council of the Federation has now declared that the provinces and territories will collaborate on their own to seek progress on health system improvements, but without federal leadership to corral regional self-interest. ${ }^{3}$ Moreover, if progress toward improving the system were sincerely the motivation, the plan seems naive. With funding already predetermined, the federal government has given away its main lever with which to drive an agreement on health system reforms.

The federal government's decision was undoubtedly also motivated in part by a desire to evade what could well have turned into an ugly political battle with the provinces. But whatever the inherent difficulties, there exists an essential and unavoidable federal responsibility toward health - including the establishment of national standards and equity of health care across the country - for which the federal health transfer is the primary tool. Rather than having the courage to show leadership in carrying out this responsibility, the federal government has instead treated the health accord renegotiation as merely a distasteful chore to be dispatched as expediently as possible.

The new federal transfer plan is a political deal calculated at best to satisfy the interests of federal and provincial politicians. But by throwing money at the health care system without fixing any of its problems, it leaves us and our patients as the losers.

\section{Matthew B. Stanbrook MD PhD \\ Deputy Editor, $C M A J$}

\section{References}

1. Bailey I, Curry B. In surprise move, Flaherty lays out health-spending plans to 2024. Globe and Mail [Toronto] 2011 Dec. 19. Available: www.theglobeandmail .com/news/politics/in-surprise-move-flaherty-lays-out-health-spending-plans-til-2024 /article2276354/ (accessed 2012 Jan. 9).

2. Stanbrook MB, Hébert PC. The federal government's senseless policy change on tobacco warning labels. CMAJ 2010;182:1939.

3. Kennedy M. Territorial leaders, premiers agree to Medicare study. Montreal Gazette 2012 Jan. 18. Available: www.montrealgazette.com/news/Territorial +leaders+premiers+agree+medicare+study/6011819/story.html (accessed 2012 Jan. 18).

Competing interests: See www.cmaj.ca/site/misc/cmaj_staff.xhtml

Correspondence to: $C M A J$ editor, pubs@cmaj.ca

CMAJ 2012. DOI:10.1503/cmaj.120073 